DIMENSI, VOL. 8, NO. $1: 1-12$

MARET 2019

ISSN: 2085-9996

\title{
EFEKTIVITAS PENGGUNAAN PLATFORM LMS SEBAGAI MEDIA PEMBELAJARAN BERBASIS BLENDED LEARNING TERHADAP HASIL BELAJAR MAHASISWA
}

\section{THE EFECT OF USING LMS PLATFORMS AS LEARNING MEDIA BASED BLENDED LEARNING TOWARD STUDENTS' LEARNING ACHIEVEMENT}

\author{
Dewi Yana', Adam ${ }^{2}$ \\ ${ }^{1}$ Prodi Pendidikan Bahasa Inggris, FKIP, UNRIKA, Indonesia \\ ${ }^{2}$ Prodi Pendidikan Bahasa Inggris, FKIP, UNRIKA, Indonesia \\ Email: alifdewi1982@gmail.com / adamedumy@gmail.com
}

\begin{abstract}
Abstrak
Penelitian ini bertujuan untuk mengukur hasil belajar mahasiwa dengan menggunakan platform Schoology, Canvas, dan Quizlet sebagai media pembelajaran berbasis blended learning. Penelitian ini dilaksanakan di Program Studi Pendidikan Bahasa Inggris Fakultas Keguruan dan Ilmu Pendidikan Universitas Riau Kepulauan. Penelitian ini menggunakan experiment dengan desain pretest-postest. Populasi penelitiannya adalah seluruh mahasiswa semester 6 yang berjumlah 78 orang yang mengambil mata kuliah ERM, dan sampelnya dipilih dengan teknik total sampling. Variable penelitian terdiri atas 3 variabel bebas $\left(X_{1}, X_{2}, X_{3}\right)$ dan 1 variabel terikat $(Y)$. Instrument yang digunakan berupa tes tertulis, yang telah di uji validitas dan reabilitasnya.Selanjutnya data penelitian yang diperoleh dianalisis secara statistic menggunakan uji ANOVA satu arah. Hasil penelitian ini (1) terjadi peningkatan hasil belajar mahasiswa menggunakan Schoology berbasis blended learning yang dibuktikan dengan selisih rata-rata skor hasil belajar pretest dan posttes mahasiswa sebesar 8.24. (2) terjadi peningkatan hasil belajar mahasiswa menggunakan Quizlet berbasis blended learning, dibuktikan dengan selisih skor hasil belajar pretest dan posttest sebesar 19,96 poin. (3) peningkatan hasil belajar mahasiswa menggunakan Canvas berbasis blended learning yang dapat dibuktikan dengan selisih skor hasil belajar mahasiswa sebesar 10.41.(4) terdapat perbedaan rata-rata hasil belajar mahasiswa dengan menggunakan platform LMS yang berbeda yang dapat disimpulkan dari hasil F hitung (3.585) lebih besar dari F tabel (3.150) dan nilai Sig 0.033 yang lebih kecil dari 0.050. Namun demikian platform LMS yang paling baik dalam meningkatkan hasil belajar mahasiswa adalah platformQuizlet. Hal ini dibuktikan dengan tabel Post Hoc yang membandingkan perbedaan rata-rata skor hasil belajar mahasiswa dengan menggunakan platform Schoology, Quizlet, dan Canvas.
\end{abstract}

Kata kunci: Platform LMS, Schoology, Canvas, Quizlet, Media Pembelajaran, Blended Learning

\begin{abstract}
This study aims at comparing the efficiency of Schoology, Canvas, and Quizlet platform based blended learning on students' learning achievement. This study was conducted at English Education Study Program of Teacher Training and Education Faculty, University of Riau Kepulauan. It was an experiment research with pretest-postest design. The population was 78 students of the sixth semester who enroll at ERM course, and the samples were selected use total sampling technique. There were three independent
\end{abstract}


variables $\left(X_{1}, X_{2} \cdot X_{3}\right)$ and one dependent variable $(Y)$. The instrument was written test which have been prior validated and reliable. The data were examined statistically use one way ANOVA. The result revealed that (1) there is an improvement in students' learning achievement using Schoology based blended learning as evidenced by the difference in the average score of pretest and posttest students' achievement of 8.24. (2) here is an improvement in students' learning achievement using Quizlet based blended learning. As evidenced by the difference between pretest and posttest learning result score of 19.96 points. (3) there is an improvement in students' learning achievement using Canvas-based blended learning which can be proved by the difference in students' learning achievement score of 10.41. (4) there is difference of mean of students' learning achievement by using different LMS platform which can be concluded from F count (3.585) is bigger than F table (3.150) and Sig 0.033 value is smaller than 0.050. However, the best LMS platform in improving students' learning achievement is the Quizlet platform. This is evidenced by the Post Hoc table comparing the average difference in students' learning achievement using Schoology, Quizlet and Canvas platforms.

Keywords: LMS Platform, Schoology, Canvas, Quizlet, Learning Media, Blended Learning

\section{PENDAHULUAN}

Era globalisai saat ini menuntut berbagai upaya dalam peningkatkan kualitas Sumber Daya Manusia (SDM).Terkait itu, beberapa tahun terakhir pemerintah negara kita telah melakukan bermacamcara dalam peningkatan mutu SDM, salah satuya adalah melalui jalur penidikan. Hal ini ditegaskan dalam Undang-undang Nomor 14 Tahun 2005 tentang guru dan dosen,bahwa "Guru adalah pendidik profesional dengan tugas utama mendidik, mengajar, membimbing, mengarahkan, melatih, menilai, dan mengevaluasi peserta didik pada pendidikan anak usia dini jalur pendidikan formal, pendidikan dasar, dan pendidikan menengah". Guru dan dosen dianggap sebagai ujung tombak dalam menciptakan SDM yang diharapkan. Sejalan dengan hal ini peningkatan kualitas kinerja dan kesejahteraan guru dan dosenpun telah menjadi perhatian pemerintah melalui sertifikasi guru dan dosen.Sehubungan dengan hal tersebut, guru dan dosen memiliki tanggung jawab penuh dalam mengoptimalkan proses pembelajaran terhadap peserta didik yang kelak akan menjadi SDM Indonesia yang mampu menghadapi persaingan globalisai.

Proses pembelajaran terkini tak terlepas dari perkembangan teknologi. Tidak dapat dipungkiri guru dan dosen bukan lagi satu-satunya sumber dalam menyajikan informasi. Generasi saat ini terlahir sebagai "digital natives" (Prensky.2001) dari kecanggihan ICT (Information Communication and Technology). Khairul Abdullah 
(2012) juga menyebut generasi ini sebagai generasi alpha dimana penggunaan teknologi digital menjadi salah satu ciri khas pola hidup mereka. Di sisi lain , zaman ini merupakan zaman"digital age" dimana hampir semua informasi yang ada berbentuk digital. Hal ini mempengaruhi karakteristik generasi yang lahir di zaman ini. Generasi muda sekarang lebih tertarik belajar dengan menggunakan gadget, smartphone, laptop, android, dan sejenisnya.Dengan mudah mereka bisa membuka google search, youtobe, google play store, dll, guna mengakses berbagai macam informasi yang terkoneksi dengan internet.Dengan demikian, guru dan dosen tidak lagi menempati posisi teratas dalam menyampaikan ilmu pengetahuan kepada generasi digital natives di zaman digital age ini.

Sehubungan dengan itu, guru dan dosen di tuntut untuk memahami bahwa perkembangan teknologi,informasi dan komunikasi berdampak dalam dunia pendidikan. Guru dan dosen harus dapat menyesuaikan diri terhadap dampak inovasi tekhnologi tersebut dalam proses pembelajaran. Di sisi lain, penggunaan media dalam proses pembelajaran memegang peranan yang penting baik bagi guru dan dosen maupun bagi peserta didik. Media yang tepat dapatmembantu guru dan dosen menyajikan bahan pembelajaran dengan baik. Guru dan dosen bisa mentrasfer ilmu pengetahuan dengan mudah dan menarik kepada mahasiswa. Penggunaan media yang tepat juga dapat memotivasi semangat belajar peserta didik.Hal ini sejalan dengan penelitian yang pernah dilakukan oleh Yana dan Darwati (2017).

Selain itu, media juga dapat meningkatkan minat dan perhatian mereka terhadap informasi yang disampaikan dalam proses pembelajaran. Sehingga mahasiswa mampu memahami dan menyerap materi pembelajaran dengan baik. Dengan demikian dapat ditegaskan bahwa mau ataupun tidak, guru dan dosen juga harus dapat memanfaatkan berbagai macam kemajuan produk ICT (Information Communication and Technology) atau TIK (Teknologi Informasi dan Komunikasi) sebagai media yang tepat dalam mendukung proses pembelajaran dan tercapainya tujuan pendidikan di zaman ini.

Contoh inovasi dalam proses pembelajaran yang memanfaatkan kemajuan ICT adalah Blended Learning. Dalam Blended Learning, proses belajar mengajar tatap muka di dalam kelas dapat dikombinasikan dengan teknologi baik online maupun offline. 
Sejauh ini, ada beberapa platform digitalyang bisa digunakan sebagai sarana proses pembelajaran.Platform-platform ini dikemas sebagai sebuah system yang disebut dengan Learning Management System (LMS). Contoh platform LMS diantaranya adalah Canvas, Moodle, Edmodo, Schoology, dan lain-lain.

Sejak akhir semester ganjil 2017/2018, kami sudah mulai menggunakan salah satu platform LMS yaitu Schoology dalam mata kuliah yang kami ampu.Berdasarkan pengamatan kami sementara ini, mahasiswa tampak tertarik dalam proses pembelajaran dan bersemangat dalam mengumpulkan tugas yang diberikan, mereka juga tampak penasaran untuk terus mengikuti perkuliahan dengan menggunakan Schoology. Di sisi lain, kami merasa lebih mudah menyediakan sumber materi utama dan link-link referensi tambahan bersifat digital seperti youtobe, slideshare, dan sejenisnya kepada mahasiswa. Selain itu, kami juga merasa lebih mudah dalam menerima tugas-tugas mahasiswa, bahkan langsung dapat memeriksa dan memberikan penilaian terhadap kinerja mereka tanpa harus mengunduhnya terlebih dahulu. Oleh karena itu melalui penelitian yang berjudul Efektivitas Penggunaan Platform LMS Sebagai Media Pembelajaran Berbasis Blended Learning terhadap Hasil Belajar Mahasiswa melakukan pembuktian secara ilmiah yang bisa menjadi referensi dalam proses pendidikan dan pengajaran dengan memanfaatkan teknologi ICT.

\section{Media Pembelajaran}

Media pembelajaran merupakan semua alat bantu yang bisa digunakan dalam menyampaikan pesan pembelajaran bagi guru atau dosen untuk meningkatkan pengalaman belajar murid atau mahasiswa.Menurut Daryanto (2010), pembelajaran dengan menggunakan media tidak mesti harus dilakukan di dalam kelas, murid dan guru bisa terlibat dalam proses belajar mengajar dengan memanfaatkan media e-learning, cd interaktif ataupun audio interaktif. selanjutnya Daryanto (2010) juga menjelaskan bahwa teknik penggunaan media pembelajaran bisa diklasifikasikan berdasarkan tempat penggunaan nya yaitu:

(1) penggunaan media di kelas, media ini di sajikan dalam ruang kelas dengan dihadiri langsung oleh guru dan siswa diwaktu yang bersamaan.

(2) Penggunaan media di luar kelas, media ini dapat digunakan oleh siswa di luar situasi kelas tanpa kontrol langsung oleh guru. Penggunaan media diluar kelas ini 
dapat dikelompokkan lagi menjadi penggunaan media tidak terprogram dan penggunaan media terprogram.

penggunaan media tidak terprogram adalah penggunaan media yang bebas di akses di masyarakat tanpa target dan tujuan tertentu. Misalnya penggunaan VCD, radio, TV, games, dan sebagainya. Sedangkan penggunaan media terprogram merupakan penggunaan media yang dirancang sebagai satu kesatuan yang sistematis untuk mencapai tujuan pembelajaran tertentu. Media terprogram memungkinkan anggotanya untuk saling berinteraksi dan hasil yang dicapai juga dapat di ukur dengan proses evaluasi. Contohnya modul pembelajaran dan e-learning.

\section{Blended Learning}

Blended learning merupakan aktifitas yang mengintegrasikan proses belajar mengajar tatap muka dengan teknologi sebagai media pembelajaran. Graham, Allen, dan Ur (2003) di dalam Graham (2006) mendefinisikan blended learning sebagai perpaduan antara proses pebelajaran dengan berbagai media, metode serta memadukan model pembelajaran tatap muka dengan model pembelajaran online. Selanjutnya sebuah laporan penelitian yang diterbitkan oleh NEALS, Melborne pada tahun 2012 menjelaskan lebih detil bahwa konsep blended learning dapat dilihat dari beragam sudut pandang dan tidak bisa diseragamkan. Secara luas blended learning bisa didefinisikan sebagai semua kegiatan pembelajaran berbasis teknologi informasi dan komunikasi, dan secara khusus sebagai sebuah praktik pembelajaran yang menyelaraskan kurikulum online dan tatap muka sesuai dengan kontek pendidikan masing-masing .

\section{Learning Management System (LMS)}

Menurut Aaron Qugley Learning Management System(LMS) adalah "a digital learning environment to manage all aspects of the learning process" hal ini dimaknai bahwa LMS merupakan sebuah lingkungan pembelajaran digital yang mengelola semua aspek proses pembelajaran. LMS dapat membantu dosen dan guru untuk (1) mengyampaikan tujuan pembelajaran, (2) mengelola jadwal pembelajaran sehingga peserta didik mengetahui apa yang akan mereka pelajari dan kapan waktu pelaksanaanya, (3) menyampaikan konten pembelajaran kepada mahasiswa meskipun tidak di dalam 
kelas, (4) mengevaluasi proses pembelajaran dan menciptakan rekam jejak pengajaran, (5) berinteraksi dengan mahasiswa, (6) menyediakan sumber referensi yang lebih luas yang bisa di akses langsung oleh mahasiswa. Di sisi lain, peran mahasiswa dalam LMS adalah (1) mengakses muatan pembelajaran, (2) mengikuti perkembangan jadwal pembelajaran, (3) mengontak atau menjalin komunikasi dengan dosen.

Ada berbagai macam platform LMS yang bisa digunakan dalam mendukung proses pembelajaran baik yang berbayar maupun yang gratis. William Fenton, seorang peneliti bidang software pendidikan mempublikasikan 9 platform terbaik untuk tahun 2018, yaitu Absorb, moodle, canvas, schoology, Blackboard, D2L, Edmodo, Quizlet, dan Google Classroom. Berdasarkan kriteria rating yang telah ia tetapkan, maka penelitian ini fokus untuk mempelajari platform yang memuat bundled course content, tidak komersial, dan menunjang LTI, yaitu canvas, schoology, Quizlet.

\section{Penelitian Terkait}

Ada beberapa penelitian yang telah dilakukan terkait dengan blended learning, diantaranya adalah penelitian Ghahari (2013), Tosun (2015), dan Eryilmaz (2015).

Ghahari dan Golestan (2013) telah menginvestigasi pengaruh blended learning terhadap keterampilan menulis bahasa asing siswa di Iran. Dia membandingkan hasilpretest dan post-test keterampilan menulis siswa yang di ajar menggunakan blended learning dengan yang di ajar menggunakan tatap muka penuh. Blended learning yang diaplikasiakan berupa computer-assisted language learning (CALL) Hasil yang ia peroleh menunjukkan bahwa keterampilan menulis siswa di kelas blended learning positif lebih signifikan dari pada kelas tatap muka penuh.

Penelitian Tosun (2015) bertujuan untuk mengetahui efektifitas penggunaan blended learning terhadap penguasaan kosa kata bahasa Inggris siswa, untuk mengetahui persepsi siswa, dan untuk mengetahui implikasi pendidikan terhadap blended learning di sebuah sekolah di Turki. Tosun melakukan experiment dengan membandingkan hasil pre-test dan post-test dua kelompok siswa (berusia 18-20 tahun) yang di ajarkan dengan blended learning dan dengan cara tradisional. Blended learning yang diaplikasikan adalah perangkat Web 2.0 yang memuat Quizlet, spelling city, dan snappy word. Hasil yang diperoleh menunjukkan bahwa penggunakan blended learning tidak berdampak 
pada penguasaan kosa kata siswa. Hal ini di perkirakan karena singkatnya waktu dalam mengaplikasikan blended learning. Namun demikian persepsi siswa adalah menyukai, puas, dan mengapresiasi proses pembelajaran dengan blended learning. Implikasi pedagogic yang diberikan dari penelitian Tosun bahwa aplikasi blended learning harus didukung dengan perangkat digital yang sesuai dengan kebutuhan dan minat siswa.

Selanjutnya penelitian yang dilakukan oleh Eryilmaz (2015) juga melalukan eksperimen terhadap 110 siswa di Universitas Atilim, Ankara untuk menguji efektifitas kelas blended learning dengan kelas tatap muka. Kelas blended learning yang diaplikasikan berupa sharing materi, gambar, dan video pembelajaran serta diskusi dan ujian secara online. Hasilnya menunjukkan bahwa prestasi belajar mahasiswa yang menggunakan blended learning posistif lebih efektif dari pada tatap muka.

\section{METODOLOGI}

Metode penelitian yang digunakan dalam penelitian ini adalah metode experimen dengan desain pretest-postes. Penelitian ini dilaksanakan pada mata kuliah Educational Research Methodology (ERM) dengan kode mata kuliah MKB-066331 di semester genap 2017/2018 Program Studi Pendidikan Bahasa Inggris FKIP. Populasi penelitiannya adalah seluruh mahasiswa semester 6 yang berjumlah 78 mahasiswa, dan sampelnya adalah mahasiswa yang mengambil mata kuliah ERM yang pilih dengan teknik total sampling.

Variabel penelitian terdiri atas:

1. Penggunaan platform canvas sebagai media pembelajaran $1\left(\mathrm{X}_{1}\right)$

2. Penggunaan platform schoology sebagai media pembelajaran $2\left(\mathrm{X}_{2}\right)$

3. Penggunaan platform Quizlet sebagai media pembelajaran $3\left(\mathrm{X}_{3}\right)$

4. Hasil belajar mahasiswa (Y)

Instrument yang digunakan dalam mengumpulkan data berupa tes tertulis. Test disusun sesuai dengan topik bahasan yang dipelajari dan dilaksanakan sebelum dan setelah perlakuan diberikan. Soal tes terlebih dahulu telah di uji validitas dan reabilitasnya. Test yang diberikan bertujuan untuk mengukur pemahaman mahasiswa terhadap materi pembelajaran yang telah dibahas. Selanjutnya data penelitian yang diperoleh di analisis secara statistic menggunakan uji ANOVAdengan bantuan SPSS. 


\section{PEMBAHASAN}

Tujuan penelitian ini adalah: (1) untuk mengetahui hasil belajar mahasiswa dengan menggunakan platform Schoology sebagai media pembelajaran berbasis blended learning pada matakuliah ERM. (2) untuk mengetahui hasil belajar mahasiswa dengan menggunakan platform Quizlet sebagai media pembelajaran berbasis blended learning pada matakuliah ERM. (3) untuk mengetahui hasil belajar mahasiswa dengan menggunakan platform Canvas sebagai media pembelajaran berbasis blended learning pada matakuliah ERM. (4) untuk mengetahui jenis platform LMS yang paling baik sebagai mendia pembelajaran berbasis blended learningdalam menigkatkan hasil belajar mahasiswa pada mata kuliah ERM.

Tujuan penelitian tersebut terjawab berdasarkan data yang telah di sajikan dalam hasil pre-test maupun hasil post-test yang dapat dirangkum dalam Tabel 1 berikut:

Tabel 1 Hasil Pretest dan Posttest

\begin{tabular}{ccccccc}
\hline STATIST & \multicolumn{3}{c}{ SKOR PRETEST } & \multicolumn{3}{c}{ SKOR POSTTEST } \\
IK & Schoology & Quizlet & Canvas & Schoology & Quizlet & Canvas \\
\hline Mean & 68.7 & 61.01 & 63.06 & 76.94 & 80.97 & 73.47 \\
Std.dev & 9.087 & 11.522 & 7.014 & 11.585 & 9.141 & 8.074 \\
std error & 1.895 & 2.403 & 1.432 & 2.365 & 1.866 & 1.648 \\
lower & 64.77 & 56.03 & 60.09 & 72.05 & 77.11 & 70.06 \\
bound & & & & & & \\
upper & 72.62 & 66 & 66.02 & 81.84 & 84.83 & 76.88 \\
bound & & 40 & 47 & 57 & 60 & 60 \\
Min & 50 & 80 & 73 & 93 & 93 & 87 \\
Max & 83 & 23 & 24 & 24 & 24 & 23 \\
N & 23 & & & & & \\
\hline
\end{tabular}

Kemudian rangkuman data di atas dapat dipaparkan sebagai berikut:

1. Hasil belajar mahasiswa dengan menggunakan platform Schoology sebagai media pembelajaran berbasis blended learning pada matakuliah ERM

Berdasarkan rangkuman tabel descriptives pre-test dan post-test yang telah disajikan, maka dapat di lihat bahwa nilai rata-rata skor hasil belajar mahasiswa menggunakan Schoology sebesar 68.7, dan 76.94. Dengan demikian tedapat selisih rata-rata skor hasil belajar mahasiswa sebesar 8.24. Hal ini dapat disimpulkan 
DIMENSI, VOL. 8, NO. $1: 1-12$

MARET 2019

ISSN: 2085-9996

bahwa terjadi peningkatan hasil belajar mahasiswa menggunakan Schoology berbasis blended learning.

2. Hasil belajar mahasiswa dengan menggunakan platform Quizlet sebagai media pembelajaran berbasis blended learning pada matakuliah ERM

Berdasarkan rangkuman tabel descriptives pre-test dan post-test tersebut, dapat dijelaskan bahw nilai rata-rata skor hasil belajar mahasiswa menggunakan Quizlet sebesar 61.01, dan 80.97 sehingga diketahui selisih skor hasil belajar pretest dengan posstes sebesar 19,96 poin. Dengan demikian, dapat disimpulkan bahwa terjadi peningkatan hasil belajar mahasiswa menggunakan Quizlet berbasis blended learning.

3. Hasil belajar mahasiswa dengan menggunakan platform Canvas sebagai media pembelajaran berbasis blended learning pada matakuliah ERM

Berdasrkan rangkuman tabel descriptives pre-test dan post-test, bahwa nilai ratarata scor hasil belajar mahasiswa menggunakan Canvas sebesar 63.06, dan 73.47 Dengan demikian tedapat selisih scor hasil belajar mahasiswa sebesar 10.41. Hal ini dapat disimpulkan bahwa terjadi peningkatan hasil belajar mahasiswa menggunakan Canvas berbasis blended learning.

4. Jenis platform LMS yang paling baik sebagai media pembelajaran berbasis blended learning dalam menigkatkan hasil belajar mahasiswa pada mata kuliah ERM.

Tabel Post Hoc pada hasil post-test telah menunjukkan perbedaan rata-rata skor hasil belajar mahasiswa dengan mengunakan platform LMS yang berbeda. Kelompok 1 yang menggunakan platform Schoology dengan jelas memperlihatkan rata-rata perbedaan dengan kelompok 2 yang mengunakan platform Quizlet lebih rendah 4,028, dan lebih tinggi 3.472 dengan kelompok 3 yang menggunakan platform Canvas. Kemudian Tabel Post Hoc tersebut juga menjelaskan bahwa ratarata perbedaan skor hasil belajar dari kelompok 2 yang menggunakan platform Quizlet lebih tinggi 4.028 diatas platform Schoology dan lebih tinggi sebesar 7.500 di bawah Canvas. Selanjutnya perbedaan rata-rata skor hasil belajar kelompok 3 yang menggunakan platform Canvas adalah 3.472 di bawah kelompok 
1 yang menggunakan platform Schoology, dan 7.500 di bawah platform Qizlet. Dengan demikian dapat di simpulkan bahwa

1. Platform Schoology lebih kecil 4.028 poin dibanding platform Quizlet

2. Platform Schoology lebih besar 3.472 poin dibanding platform Canvas

3. Platform Quizlet lebih besar 4.028 poin dibanding platform Schoology

4. Platform Quizlet lebih besar 7.500 poin dibanding platform Canvas

5. Platform Canvas lebih kecil 3.472 poin dibanding platform Schoology

6. Platform Canvas lebih kecil 7.500 poin dibanding platform Quizlet

Dengan demikian maka dapat dimaknai bahwa platform yang paling baik dalam meningkatkan hasil belajar mahasiswa adalah platformQuizlet. Selanjutnya untuk membuktikan hipotesis penelitian yang telah ditetapkan, hipotesis statistik dapat dirumuskan sebagai berikut:

Jika $\mathrm{F}$ hitung < F tabel berarti H0 diterima dan Ha ditolak;

Jika F hitung > F tabel berarti H0 ditolak dan Ha diterima.

Berdasarkan tabel ANOVA posttest ditemukan nilai $\mathrm{F}$ hitung adalah 3.585, nilai df between groups adalah2 dan within groups adalah 69. Sehingga dapat ditentukan nilai $\mathrm{F}$ tabel dengan taraf signifikansi 5\% adalah 3.150. Dengan demikian, F hitung (3.585) lebih besar dari Ftabel (3.150). Dengan demikian dapat disimpulkan bahwa $\mathrm{H}_{0}$ ditolak dan $\mathrm{H}_{\mathrm{a}}$ diterima. Hal ini dapat diartikan bahwaada perbedaan rata-rata hasil belajar mahasiswa dengan menggunakan platform LMS yang berbeda. Sejalan dengan kesimpulan tersebut, jika menggunakan nilai signifikansi (5\%) pada tabel ANOVA, maka dilihat bahwa nilai Sig adalah 0.033, nilai ini lebih kecil dari 0.050. dengan demikian hipotesis nihil $\left(\mathrm{H}_{0}\right)$ juga ditolak. Hal ini menegaskan kembali bahwa ada perbedaan rata-rata hasil belajar mahasiswa pada matakuliah ERM dengan menggunakan platform Schoology, Quizlet dan Canvas.

\section{KESIMPULAN}

Berdasarkan hasil dan pembahasan, maka penelitian ini dapat disimpulkan sebagai berikut: 
1. Terjadi peningkatan hasil belajar mahasiswa menggunakan Schoology berbasis blended learning yang dibuktikan dengan selisih rata-rata skor hasil belajar pretest dan posttes mahasiswa sebesar 8.24.

2. Terjadi peningkatan hasil belajar mahasiswa menggunakan Quizlet berbasis blended learning.yang dibuktikan dengan selisih skor hasil belajar pretest dan posttest sebesar 19,96 poin.

3. Terjadi peningkatan hasil belajar mahasiswa menggunakan Canvas berbasis blended learning yang dapat dibuktikan dengan selisih skor hasil belajar mahasiswa sebesar 10.41 .

4. Terdapat perbedaan rata-rata hasil belajar mahasiswa dengan menggunakan platform LMS yang berbeda yang dapat disimpulkan dari hasil F hitung (3.585) lebih besar dari F tabel (3.150) dan nilai Sig 0.033 yang lebih kecil dari 0.050 . Namun demikian platform LMS yang paling baik dalam meningkatkan hasil belajar mahasiswa adalah platformQuizlet. Hal ini dibuktikan dengan tabel Post Hoc yang membandingkan perbedaan rata-rata skor hasil belajar mahasiswa dengan menggunakan platform Schoology, Quizlet, dan Canvas.

\section{REFERENSI}

Aaron Qugley a digital learning environtment to manage all aspects of the learning process.https://www.linkedin.com/learning/learning-management-systems-lmsquick-start/what-is-an-lms.

Daryanto. 2010. Media Pembelajaran: Peranannya Sangat Penting dalam Mencapai Tujuan Pembelajaran. Yogyakarta: Penerbit Gava Media.

Eryilmaz. 2015. The Effectiveness of Blended Learning Environtments. Contemporary Issues in Education Rsearch- $4^{\text {th }}$ Quarter Vol 8,No 4, Pp 251-256. The Clute Institute.

Ghahari and Golesan. 2013. The Effect of Blended Learning vs Classroom Learning Techniques on Iranian RFL Learners Writing. International Journal of Foreign Language Teaching \& Research- vol 1-issue 3- Spring 2013. 
Graham, C. R. (2006). Blended learning systems: Definitions, current trends and future directions.https://www.researchgate.net/publication/258834966

Khairul Abdullah. 2012. http://khairulabdullah.com/generasi-alpha-generasi-selepas-xy$\mathrm{z} /$.

Prensky,Marc .2001. Digital Natives, Digital Immigrants Part 1, On the Horizon, Vol. 9 Issue: 5, pp.1-6, https://doi.org/10.1108/10748120110424816

Tosun. 2015. The Effects of Blended Learning on EFL Student's Vocabulary Enhancement. Procedia-Social \& Behavoiur Science 199 (2015).641-647.

Yana, D., \& Darwati, F. F. (2017). The Implementation of Android-Based Application as a Media for Teaching English in Simple Present Tense. Anglo-Saxon,8(2), 158165.http://journal.unrika.ac.id/index.php/jurnalanglo-saxon/article/view/1215/945

The Departement of Education and Early Childhood Development. 2012.Blended learning. A synthesis of research findings in Victorian Education 2006-2011. Melbourne: NEALS

Undang-Undang Nomor 14, Tahun 2005 tentang guru dan dosen

William Fenton.2018. The Best (LMS) Learning Management Systems for 2018.http://sea.pcmag.com/absorb-lms/10984/guide/the-best-lms-learningmanagement-systems-for-2018 